\title{
How Indonesian's Online News Papers Report the Conflict between Palestine and Israel-A Case of Republika.co.id and Kompas.com
}

\author{
Ibrahim T. I. Ukk, Duc Anh Linh Bui \\ School of Journalism and information Communication, Huazhong University of Science and Technology, Wuhan, China \\ Email: ibrahimokah@hust.edu.cn,anhlinhajc1987@yahoo.com
}

How to cite this paper: Ukk, I.T.I. and Bui, D.A.L. (2019) How Indonesian's Online News Papers Report the Conflict between Palestine and Israel-A Case of Republika.co.id and Kompas.com. Open Journal of Social Sciences, 7, 290-331. https://doi.org/10.4236/jss.2019.75025

Received: March 29, 2019

Accepted: May 26, 2019

Published: May 29, 2019

Copyright ( 2019 by author(s) and Scientific Research Publishing Inc. This work is licensed under the Creative Commons Attribution International License (CC BY 4.0).

http://creativecommons.org/licenses/by/4.0/ c) (i) Open Access

\begin{abstract}
Purposes: This research is to know how the two online media report the conflict between Israel-Palestine perceived from the topics and the content. The analysis used in this study using the methods of discourse analysis and content analysis to get the answers to the formulation of the problem. Methodology/Approach: Content analysis was conducted to answer the formulation of the problem (quantitative method) using the chi-square. This study examined the entire contents of the news of the two online news media republika.co.id and kompas.com on the conflict between Israel and Palestine reported during 2009-2010. We use all data population is 1403 news. Findings: News categories: attack, cease fire, and expansion are significantly not different between the years 2009 to 2010 of the online news media studied (kompas and republika), it can be seen on the acquisition value of $\chi^{2}<3.84$ ( $\chi_{\text {table }}^{2}$ ) or has a probability value $>0.05$. The seven categories of news, namely: negotiation, agreement, demonstration, victim, cooperation, offensive, and assistance have value $\chi^{2}>3.84\left(\chi_{\text {table }}^{2}\right)$ or have a probability value $<0.05$, which means that the category of news between 2009 and 2010 has a different number of news media coverage of both online media (kompas and republika). Both the online media have presented the news about Israel and the Palestinian conflict with a good, impartial one of the country experiencing conflict. So everything is presented in a balanced and candid way. The majority of Indonesian people do not like the aggression committed by Israel against the Palestinians.
\end{abstract}

\section{Keywords}

News, Category, Media Online, Conflict 


\section{Introduction}

Conflict is an event that often raises the pros and cons and both casualties and material casualties. Tensions occur between countries or parties in conflict are usually caused by differences in opinions or views, either on the border and territory rights, religious views, and cultural differences are often also a trigger of conflict. Conflicts can also occur because of a political game, both politically between individuals, groups, and the state. Sometimes a big role in politics has sparked a conflict or war.

The news media has become the central arena for political conflicts. It is not surprising when the role of the news media in political conflicts is an issue that has received a good deal of public attention in recent years. Policy makers, journalists, and social scientists all point to the important role of the press in events such as the war in Bosnia, the conflict in Somalia, the Gulf war, the Palestinian intifada, the events at Tiananmen Square, and the massive protests throughout Eastern Europe and Russia in the dying days of communist regimes [1].

The idea of "new media" captures both the development of unique forms of digital media, and the remaking of more traditional media forms to adopt and adapt to the new media technologies. Indeed, the lines between "new" and "old" media are hard to draw. The content of new media such as on World Wide Web sites is frequently recombinant-derived from already existing media content developed in other formats (printed text, photographs, films, recorded music, television) and reproduced in a digital format, rather than involving the generation of new content [2]. New media development has also involved the giants of traditional media establishing a digital presence and revising their established media products, as well as new media content, and the emergence of new media forms such as newspapers and news services, cinema, and radio can be taken as being illustrative of this duality in the development of new media, involving what [3] describes as "the rapid development of new digital media and the nearly as rapid response by traditional media".

As one of the Non-Aligned Movement (NAM) country, Indonesian government always tried to remain neutral in any conflict that occurs between nations, for Indonesia itself has a variety of cultures and differences. Indonesia is a country respecting any existing differences, either in the form of religion, opinion, politics, culture, etc.

Indonesia is a country that has diverse cultures, religions, and political perspective as well as a variety of social status that can cause a variety of views among the community. Multicultural Indonesia's make Bhineka Tunggal Ika as the State motto, still often experience tension and friction between groups in society because of differences in ethnicity, race, and religion. So the issue of conflict will be news that interesting to be listened by the society.

Reporting on the conflict between Israel and the Palestinian state that began in 2002 became a hot topic in Indonesia, where the growing opinions in the Indonesian community, cause have different interests, religion, business, and the 
recognition of independence of the country. Indonesia has one of the frequent conflicts with domestic and neighboring countries like Malaysia because the interests of the state and tribal differences that causes this to happen recognition of independence of any problems experienced by Indonesia. Dutch recognize the independence of Indonesia recently while Indonesia itself proclaimed its independence in 1945 (67 years ago of independence).

Internet today has become one of the means to provide information to public. Coverage of all events happening in the world today which is always updated from home to line would be very easy to access via the internet. Topics of conflict will be a very interesting issue for everyone in any country he/she belongs to, where one of them is the country of Indonesia.

As a country with the biggest Moslem population in the world, the conflict between Palestine and Israel became a very important topic to be read. This is a question for the Indonesian community in particular or the worlds in general have questioned whether the conflict between Palestine and Israel is a state of conflict or religious conflict.

Phenomenon of conflict between the two countries is very important to be studied for the world of journalism to provide complete and correct information on Indonesian society. Differences issues and conflicts between Israel and the Palestinians to be one interesting topic to be researched, but Indonesia has a multicultural and diverse religious communities also have different views respond issues and conflicts are growing, both in country and abroad.

Although issues of Israel-Palestine conflict is interesting for every media, the way the media reports the issues would not be the same, even though the reports are very quite different. This happens due to a number of reasons such as the orientation of the media, standard of news objectivity, etc.

\section{Communication}

\subsection{Definitions of Communication}

In this simplest form communication is the transmission of a message from a source to a receiver. For over 60 years now, this view of communication has been identified with the writing of political scientist Harold Lasswell (1948). He said that a convenient way to describe communication is to answer these questions:

1) Who? Source

2) Say what? Message

3) Through which channel? Channel

4) To whom? Receiver

5) With what effect? Feedback

Expressed in terms of the basic elements of the communication process, communication occurs when a source sends a message through a medium to a receiver producing some effect. Straightforward enough, but what if the source is a professor who insists on speaking in a technical language far beyond the re- 
ceiving students' level of skill? Obviously, communication does not occur. Unlike mere message-sending, communication requires the response of others. Therefore, there must be a sharing (or correspondence) of meaning for communication to take place. A second problem with this simple model is that it suggests that the receiver passively accepts the source's message. However, if our imaginary students do not comprehend the professor's words, they respond with "Huh?" or look confused or yawn. This response, or feedback, is also a message. The receivers (the students) now become a source, sending their own message to the source (the offending professor), who is now a receiver. Hence, communication is a reciprocals and ongoing process with all involved parties more or less engaged in creating shared meaning. Communication, then, is better defined as the process of creating shared meaning.

The communication process consists of a message being sent and received. The message may be verbal or non-verbal. The same basic principles apply whether humans, animals, other forms of life, or combinations of these are involved. Your challenge, as an instructor, is to not merely communicate with your students but to communicate effectively. Effective communication involves a message being sent and received.

The classic model that stresses the dominance of the media was developed by Wilbur Schramm (1982), often credited as the founder of mass communication studies. He created what is known as the Source-Message-Channel-Receiver (SMCR) model. The SMCR mode of mass communication describes the exchange of information as the message passes from the source to channel to the receiver, with feedback to the source.

\section{1) Source (Sender)}

Is the originator of the communication [4].

\section{2) Message}

Is the Content of the communication, the information that is to be exchanged.

\section{3) Channels}

Is the medium or transmission system used to convey the message from one place to another. A channel is an electronic or mechanical system that links the source to the receiver [5].

In economic terms, "the media" show up as very disparate, although they do have some shared features. Most obviously there are a number of different, often competing, media (newspapers, television, film, radio, etc.) within the same national "media system", each with different advantages and disadvantages for producers, advertisers and consumers. Equally obviously, media are structured geographically, with media provision geared to population considered as international, national, regional, city or local markets.

Media (especially press and broadcasting) should provide a comprehensive supply of relevant news and background information about events in the society and the world around [6].

The media can: 
a) cause intended change,

b) cause unintended change,

c) cause minor change (form or intensity),

d) facilitate change (intended or not),

e) reinforce what exists (no change),

f) prevent change [7].

\section{4) Receiver}

Is the destination of the communication [8].

The three modes of (mutual) audience orientation and related experiences can be approximately summed up as follows: Cognitive processing; sharing and normative commitment; attention giving.

There are types of audiences as follows:

- Audience as target

In communication process is considered primarily as the sending of signals or messages over time for the purposes of control or influence. The receiver, and thus audience are perceived as a destination or target for the purposeful transfer of meaning. This model applies, for example, to education and many kinds of public information campaign, as well as some kinds of advertising. Its basic process is one of "cognitive processing".

- Audience as participants

Communication is defined in terms of sharing and participation, increasing the commonality between sender and receiver, rather than in terms of changing "receivers" in line with the purpose of the "sender". Communication is not primarily instrumental or utilitarian, but normative. Audience members are essentially participants.

- Audience as spectators

The third audience type arises in a model of communication in which the source does not seek to transmit information or beliefs, but simply to capture the attention of an audience, regardless of communicative effects. Audience attention as "spectatorship" is involving, but not for long. It implies no "transfer of meaning" or sharing or deepening of ties between sender and receiver [9].

\section{5) Effect/Feedback}

Is mechanism between the source and the receiver regulates the flow of communication [10].

\subsection{The Stimulus-Response Model}

Individual response and individual reaction can be dealt with together under this heading, since they share the same underlying behavioral model, that of stimulus-response or conditioning. Although appropriate here, the model also has a much wider potential application. The model's main features can be simply as follows:

Single message $\rightarrow$ individual receiver $\rightarrow$ reaction.

It applies more or less equally to intended and to unintended effects, although 
there is a significant difference between responses (implying some interaction on the part of the receiver). A more extended version of the basic response and learning process as it occurs in persuasion and opinion formation is indicated by McGuire (1973) in the form of six stages in sequence: presentation, attention, comprehension, yielding, retention, overt behavior [11].

\subsection{Types of Communication}

\subsubsection{Interpersonal Communication}

Encoded messages are carried by a medium, that is, the means of sending information. Sound waves are the medium that carries our voice to friends across the table; the telephone is the medium that carries our voice to friends across town. When the medium is a technology that carries messages to a large number a people-as newspapers carry the printed word and radio conveys the sound of music and news-we call it a mass medium (the plural of medium is media). The mass media we use regularly include radio, television, books, magazines, newspapers, movies, sound recordings, and computer networks. Each medium is the basis of a giant industry, but other related and supporting industries also server them and us-advertising and public relations, for example. In our culture we use the word media and mass media interchangeably to refer to the communication industries themselves. We say, "The media entertain" or "The mass media are too conservative (or too liberal)" [12].

\subsubsection{Mass Communication}

We speak, too, of mass communication. Mass communication is the process of creating shared meaning between the mass media and their audiences. Schramm recast his and Osgood's general model of communication to help us visualize the particular aspects of the mass communication process. This model and the original Osgood-Schramm model have much in common-interpreter, encoding, decoding, and messages-but it is their differences that are most significant for our understanding of how mass communication differs from other forms of communication. For example, whereas the original model includes "message", the mass communication model offers "many identical messages". In addition, the mass communication model specifies "feedback", whereas the interpersonal communication model does not. When two or a few people communicate face-to-face the participants can immediately and clearly recognize the feedback residing in the reciprocal messages (our boring professor can see and hear the student's disenchantment as they listen to the lecture). Things are not nearly as simple in mass communication [13].

In Schramm's mass communication model, feedback is represented by a dotted line labeled delayed inferential feedback. This feedback is indirect rather than direct. Television executives, for example, must wait a day, at the very minimum, and sometimes a week or a month, to discover the ratings for new programs. Even then, the ratings measure only how many sets are tuned in, not whether people liked or disliked the programs. As a result, these executives can 
only infer what they must do to improve programming; hence the term inferential feedback. Mass communicators are also subject to additional feedback, usually in the form of criticism in other media, such as a television critic writing a column in a newspaper. The differences between the individual elements of interpersonal and mass communication change the very nature of the communication process.

As a result, interpersonal communication is often personally relevant and possibly even adventurous and challenging. In contrast, the distance between participants in the mass communication process, imposed by the technology, creates a sort of "communication conservatism". Feedback comes too late to enable corrections or alterations in communication that fails. The sheer number of people in many mass communication audiences makes personalization and specificity difficult. As a result, mass communication tends to be more constrained, less free. This does not mean, however, that it is less potent than interpersonal communication in shaping our understanding of ourselves and our world.

Media theorist [14] recognized this and offered a cultural definition of communication that has had a profound impact on the way communication scientists and others have viewed the relationship between communication and culture. Carey wrote, "Communication is a symbolic process whereby reality is produced, maintained, repaired and transformed".

[15] definition asserts that communication and reality are linked. Communication is a process embedded in our everyday lives that informs the way we perceive, understand, and construct our view of reality and the world. Communication is the foundation of our culture. Its truest purpose is to maintain ever-evolving, "fragile" cultures, communication is that "sacred ceremony that draws persons together in fellowship and commonality" [16].

\subsection{Mass Communication}

\section{Defined of Mass Communication}

Mass communication as a set of media institutions. A common view of mass communication is as a set of media institutions-the organizations that send mediated messages through various channels. In fact, most college-level introductory texts on the subject of mass communication are organized according to this view, with a chapter devoted to each of the mass media industries, including newspapers, magazines, books, film, radio, television, and their "support" industries, advertising and public relations.

The defining feature of these media institutions is their capacity for mass production and dissemination of messages [17] and others have argued, the technologies powering the mass media unshackled communication from the bounds of time and space, thereby enabling for the first time in history instant communication with a large and largely anonymous audience. Media institutions such as film studios and television networks crystallized quickly to capitalize on and profit from the new opportunity for communication on a massive 
scale. These organizations were wildly successful, which enabled them to grow large, although the technologies themselves kept entry costs high, allowing only a few companies to dominate each media industry. Thus, by the middle of the 20th century, the mass media could be characterized by their "bigness and fewness" [18].

Mass communication theory can be divided into five categories; social scientific, normative, operational, everyday, and critical theory. Another way to classify mass communication theory is by its goals: social scientific theory seeks prediction and control; critical theory seeks emancipation and freedom; hermeneutic theory tries to understand how those in an observed social situation interpret that situation. The explanatory power of mass communication theory, however, is constantly challenged by the presence of many media, their many facets and characteristics, their constant change, and always-developing audience, and the ever-evolving nature of the societies that use them [19].

As effects researchers increasingly studied mass communication from the audience site, there seemed to be fewer effects that could be attributed to mass communication. Audiences were only idiosyncratically attentive to the intended meanings of messages (content) and sometimes highly erratic in terms of their attention to the media (producers) altogether. For example, the "uses and gratifications" approach to audience research asserts that the audience member's attentiveness is strictly "motivated and directed toward the gratification of certain individually experienced needs" [20]. What kinds of gratification can distance learning create for its communities? (This question points to a research agenda with potential relevance for the field of distance education; however, it would require knowledge of mass communication research literature).

Following the lead of Lerner and Schramm, mass communication scholar Everett Rogers highlighted the role of mediated communication in his work on the Diffusion of Innovations [21]. He advanced a top-down model of communication in which innovations in education as well as other social practices, such as agricultural and governmental arrangements, are dependent on rising levels of media penetration and the identification of indigenous elites (innovators) to lead the economic, political and social changes that are part and parcel of national development. Each of these researchers (Schramm, Lerner and Rogers) thought of new media as neutral objects through which messages passed from producers to audiences. They adapted the more general theories of mass communication that highlighted the impact or effects of media on an individual's attitudes and behaviors to conduct research and recommend policies for developing countries. Their policy recommendations were based most often on the findings of surveys conducted by various US-government agencies and educational foundations (in particular the data collected in Asia and Latin America) [22].

\subsection{Types of Mass Communication}

\subsubsection{Printed of Mass Communication}

1) Newspaper 
A newspaper is a scheduled publication containing news of current events, informative articles, diverse features and advertising. It usually is printed on relatively inexpensive, low-grade paper such as newsprint [23].

General-interest newspapers typically publish stories on local and national political events and personalities, crime, business, entertainment, society and sports. Most traditional papers also feature an editorial page containing editorials written by an editor and columns that express the personal opinions of writers. The newspaper is typically funded by paid subscriptions and advertising.

A wide variety of material has been published in newspapers, including editorial opinions, criticism, persuasion and op-eds; obituaries; entertainment features such as crosswords, sudoku and horoscopes; weather news and forecasts; advice, food and other columns; reviews of radio, movies, television, plays and restaurants; classified ads; display ads, radio and television listings, inserts from local merchants, editorial cartoons, gag cartoons and comic.

2) Book

Books are diverse and hard to characterize in general terms. According to the Association of American Publishers, the major categories of book genres are as follows:

a) Trade books: hard- or soft-cover, including "serious" fiction and most nonfiction such as cookbooks, biographies, how-to books, and art books.

b) Professional books: Reference or professional education books aimed at doctors, lawyers, scientists, researchers, managers, and engineers such as The Programmer's Guide to Windows NT.

c) Elementary, high school and college textbooks. Such as media Now. Communications Media in the information Age, Fifth Edition.

d) Mass market paperbacks. Softbound books, generally smaller in format and less expensive than trade paperbacks such as Teeth of the Tiger by Tom Clancy.

e) Religious books. Bibles, other sacred texts, hymnals, prayer books, and commentaries.

f) Book club editions. Clubs that publish, sell, and distribute their own edition of mass market books, professional books, and other specialized books. For example: The Quality Paperback Club, for instance, issues trade paperback versions of current hardcover best-seller.

g) Mail-order publications. Books largely created by publishers to be sold by mail. These are usually classic novel or specialized series on such subjects as cooking, western history, wars, cars, and aviation such as the Time-Life series on cowboy.

h) Subscription reference books. Books sold as a package or series, including encyclopedias, atlases, dictionaries, a glossaries, and thesauruses.

i) Audiovisual and multimedia. Videotapes, CD-ROM, computer discs, slides, and audiotape marketed primarily to schools, companies, and training groups, but also to individuals, by both regular publishing houses and new multimedia publishing companies. For example: Microsoft's Encarta encyclopedia series. 
3) University and scholarly presses

Scholarly or artistic books of primary appeal to scholars and libraries such as Jan Nederveen Pieters's Globalization and Culture.

Magazines began to develop in Great Britain in the 1700s. They carried fiction and nonfiction in varying degrees, depending on the readership.

Newsmagazine is a weekly magazine focused on news and analysis [24]. Examples of newsmagazine are Time, Life, and Newsweek. They covered weekly events, politics, and arts and contained reviews, travelogues, short stories, and serialized fiction; they were aimed at educated elite.

4) Novel

Novel is extended fictional works usually of book length. The antecedents of novels are about daily life, romances, mysteries, and horror or terror existed well before the advent of printing [25].

\subsubsection{Electronic Mass Communication}

1) Radio: Early radio broadcast Morse code not music. It used radio waves that composed of electromagnetic energy and rise and fall in regular cycles. Radio gets improvements of system time by time.

The technologies of radio progress are as follows:

a) High Definition Radio transmits audio that has been converted to computer data, as in a CD recording, over the air from earth bound radio transmitters to special digital receivers.

b) Satellite Radio's Technology.

The broadcast must hurry if they want to remain the leading source of live sound. Radio transmits music via satellite to compact receivers via wafer-shaped antennas that can be placed on the roof of a car, by passing earthbound radio stations entirely.

c) Internet Radio's technology.

More radio stations started putting their signals on websites, but many web radio station are completely independent from broadcast radio stations are available only on the Internet.

d) Webcast.

Webcast or Internet radio stations use varying technologies for "streaming" a continuous transmission over the Internet. In another words, a webcast is a broadcast on the World Wide Web [26].

2) Radio News

During the medium's first three decades, the term network and news were virtually synonymous. Most of the news broadcast over America radio stations emanated from the networks. The public's dependence on networks radio news reached its height during World War II. As television succeeded radio as the mainstay for entertainment programming in the 1950s and the 1960s, the network concentrated their efforts in supplying affiliates with news and information feeds. This approach helped the network regain their footing in radio after a period of substantial decline by the mid-1960s, the majority of the nation's stations 
utilized one of the four major networks for news programming.

Several state and regional news networks do well, but big three, ABC, NBC, and CBS, continue to dominate. Meanwhile, independent satellite news and information networks have joined the field and more are planned [27].

Radio Sportscast: Sports is most commonly presented as an element within newscasts. While many stations air sports as programming features unto themselves, most stations insert information, such as scores and schedules of upcoming games, at a designated point in a newscast and call it sports largely depends on its audience [28]. Stations gearing their formats for younger or women often all but ignores sports. Adult-oriented stations, such as Middle-of-the-Road, will frequently offer a greater abundance of sports information, especially when the nation is located in an area that has a major league team.

The style of a news story and a sports story may differ considerably. While news is written in a no-frills, straight forward way, sports stories often contain colorful colloquialisms and even popular slang.

The wire services and networks are the primary source for sports news at local stations. On the other hands, information about the outcome of local games, such as high school football and so forth, must be acquired firsthand. This usually entails a call to the team's coach or a direct report from a stringer or reporter [29].

Radio News and the FCC: The government takes a greater role in regulating broadcast journalism than it does print. Whereas it usually maintains a hand-off position when it comes to newspapers, the government keeps a watchful eye on radio to ensure that it meets certain operating criteria. Since the FCC perceives the airways as public domain, it expects broadcasters to operate in the public's interest [30]. The FCC requires that radio reporters present news factually and in good faith. Stories that defame citizens through reckless or false statements may not only bring a libel suit from the injures party but action from the FCC, which views such behaviour on the part of broadcasters as contrary to the public interest.

\section{3) Television}

Television has been continuously evolving, and it would be risky to try to summarize its features in terms of communicative purposes and effects. Initially the main genre innovation of television stemmed from its capacity to transmit many pictures and sound live and thus act as a "window on the world" in real time. A second important feature of television is the sense of intimacy and personal involvement that it seems able to cultivate between the spectator and presenter or the actors and participants on screen.

The progressing of television systems:

a) Cable television transmits television program via coaxial cable or fiber.

b) Television receive-only (TVRO) was a backyard satellite system that let individual homes receive the same channels intended for cable systems.

c) High-definition television (HDTV) is digital television that provides a wid- 
er and clearer picture [31].

There are some products of television, as follows:

a) Network News.

b) Local News. Most programs produced by local television stations are either newscasts or magazines-format shows.

c) Sport. The networks also maintain their own sports divisions that supply the announcers, equipment, and staff for broadcasts of sporting events.

d) Public TV.

e) Cable Production. National cable networks follow the same content acquisition strategies as the national broadcast networks, but local production is rather limited. Many cables systems produce their own local origination (created within the community by having no direct control. cable operator). Most cable systems also maintain community access channels over which the operator [32].

The status of television as the most "massive" of the media in terms of reach, time spent and popularity has barely changed over thirty years and it adds all the time to its global audience. Television is considered to be the main source of news and information for most people and as the main channel of communication between politicians and citizens, especially at election time. Television is also the largest single channel of advertising in nearly all countries, and this has helped to confirm its mass entertainment functions [33].

Television has been continuously evolving, and it would be risky to try to summarize its features in terms of communicative purposes and effects. Initially the main genre innovation of television stemmed from its capacity to transmit many pictures and sound live and thus act as a "window on the world" in real time. A second important feature of television is the sense of intimacy and personal involvement that it seems able to cultivate between the spectator and presenter or the actors and participants on screen.

The status of television as the most "massive" of the media in terms of reach, time spent and popularity has barely changed over thirty years and it adds all the time to its global audience. Television is considered to be the main source of news and information for most people and as the main channel of communication between politicians and citizens, especially at election time. Television is also the largest single channel of advertising in nearly all countries, and this has helped to confirm its mass entertainment functions [34].

4) Film

Film began at the end of the $19^{\text {th }}$ century as a technological novelty, but what it offered was scarcely new in content or function. It transferred to a new means of presentation and distribution an older tradition of entertainment, offering stories, spectacles, music, drama, humors, and technical tricks for popular consumption. It was also almost instantly a true mass medium in the sense that it quiet quickly reached a very large proportion of populations, even in rural areas. As a mass medium film was partly a response to the "invention" of leisure-time out of work-and an answer to the demand for economical and (usually) res- 
pectable ways of enjoying free time for the whole family.

Film is centered around storytelling, the creation of striking and memorable that draw people in to spend fairly high amounts of money to see them, often repeatedly [35]. The basic film genres are comedy, drama, action, horror, science fiction, classic, family, westerns, animation and foreign. Actually, in the 1930s movies emphasized their new attraction, sound, by creating a series of extravagantly produced musicals, with dancing and singing. The other main genres of the 1930s and 1940s were comedies, crime dramas, suspense, mysteries, historical epics, film noir, and detective movies. Film has been improved by increasing the number of frames or images per second, making the image wider, and adding color. Video (and DVD) has become the most profitable distribution channels for film.

The characterization of the film as "show business" in a new form for an expanded market is not the whole story. There have been three other significant strands in film history. First, the use of film for propaganda is noteworthy, especially when applied to national or societal purposes, based on its great reach, supposed realism, emotional impact and popularity. The practice of combining improving message with entertainment had been long established in literature and drama, but in film were the capacity to reach so many people and to be able to manipulate the seeming reality of the photographic message without loss of credibility. The two other strands in film history were the emergence of several schools of film art [36] and the rise of the social documentary film movement Internet [37].

In respect of the emergence of any new medium, we can at least recognize the claim of the Internet (and World Wide Web) to be considered as a medium in its own right on the grounds of its now extensive diffusion. It began primarily as a non-commercial means of intercommunication and data exchange between professionals, but its more recent rapid advance has been fuelled by its potential as a purveyor of goods and many profitable services and as an alternative to other means of interpersonal communication [38]. The medium is not yet mature or clearly defined, in line with [39] assessment that there is "no overarching killer application of online interaction". Diffusion proceeded most rapidly in North America and Northern Europe. In the USA it appeared to reach a ceiling of diffusion in 2001, at around $60 \%$ to $70 \%$ of the population [40], but with much continuing flux. These authors believe it will reach the same high penetration as television and the telephone in another half generation. Actual use varies considerably in amount and type. The fact that uses of the Internet are often clearly not mass communication is relevant but not a decisive argument. Some applications of the Internet, such as online news, are clearly extensions of newspaper journalism, although online news itself is also evolving in new directions, with new capabilities of content and new forms (as where the public adopts the role of journalist) [41].

The Internet's claim to recognition is based in part on its having a distinctive 
technology, manner of use, and range of content and services, and a distinct image of its own. The Internet is not owned, controlled or organized by any single body, but is simply a network of internationally interconnected computers operating according to agreed protocols. Numerous organizations, but especially service providers and telecommunication bodies, contribute to its operation [42]. The Internet as such does not exist anywhere as a legal entity and is not subject to any single set of national laws or regulations [43]. However, those who use the Internet can be accountable to the laws and regulations of the country in which they reside as well as to international law [44].

Online media or internet media is one of the most advanced mass communications. As it is the journalism world will join the world utilize the internet by developing an online news media. In online news media, the public can participate directly interact with their comment or opinion on a news story submitted. In online news media public opinion can be a useful input for a news provider; this is not shared by conventional news media.

The internet represents the newest, most widely discussed, and perhaps most significant manifestation of new media. When terms such as "cyber-space", the "virtual world", the "network society" and the "information superhighway" are used in relation to new media, they typically refer to the new possibilities arising from the development of the internet. The internet constitutes the electronic network of networks that link people and information through computers, and increasingly through other digital media technologies, and allow for both interpersonal communication and information retrieval [45]. It is essential to note that the internet refers to both a technical infrastructure of computers and other digital devices permanently connected through high-speed telecommunications networks, and to the forms of content, communication, and information sharing that occurs through these networks. Internet usage involves person-to-person communication, group communication, and global publishing and information provision, through electronic mail (e-mail), news groups, chat rooms, mailing lists, and the World Wide Web.

\section{New Media}

The temptation in any discussion of new media is to equate "new media" with what has been most recently developed [46]. For example, the Internet is considered a new media technology in contrast to television, which is seen as an old media form. Indeed, there is a line of thought that sees television as a tool for tyrants, and looks to internet to revive entrepreneurship, free thought, and civic participation. More commonly, the Internet is seen as new when compared with television because it is networked, interactive, enable two-way communication, and allows its users to be both producers as well as consumers of content.

\subsection{Online Newspaper}

1) Defined of Online Newspaper: Online newspaper currently balance the web presence of major national newspapers, like New York Times, and the wild 
growth of new types of internet-only "newspaper" that range from blogs to neighborhood newsletters. A huge diversity of forms is growing to meet a staggering number of would-be writer and readers. As is many aspects of the internet, it helps a newspaper online to have a long reputation based in a successful exciting newspaper. Online versions of existing papers can add a number of features. Several major of newspaper now send out an email to readers who have registered for the service with daily highlights [47].

2) The Types of Online Newspapers: We've cited statistic about dailies and weeklies, but these categories actually include many different types of papers. Let's take a closer look at some of them.

a) National Daily Newspapers: We typically think of the newspapers as a local medium, our town's paper.

b) Large Metropolitan Dailies: To be a daily, a paper must be published at least five times a week. The circulation of big-city dailies has dropped over the past 30 years, with the heavy losses of the evening papers offsetting increases for the morning papers.

c) Suburban and Small-Town Dailies: As the United States has become a nation of transient suburb dwellers, so too has the newspapers been suburbanized.

d) Weeklies and Semiweeklies: many weeklies and semiweeklies have prospered because advertisers have followed them to the suburb.

e) The Ethnic Press: One hundred and thirty US cities are served by at least one Spanish-language publication, up from 80 in 1995.

f) The Alternative and Dissident Press: Another type of paper, most commonly a weekly and available at no cost, is the alternative press.

g) Commuter Papers: Modeled after a common form of European newspapers, free dailies designed for commuters are becoming commonplace in America's biggest cities [48].

\subsection{Design in Online Newspaper}

The presentation of the contents of newspaper becomes an exercise in design by which the contents are to the reader. It is a process akin to packaging and, as with most forms of packaging, the visual display is rooted in psychology.

Page design has three aims (F. W. Houdgson, 1998: p. 84) as follows:

1) To attract the eye of a potential reader.

2) To signpost the various items and signal their relative importance.

3) To give a newspaper recognizes visual character.

On each page, headlines, text and pictures are used to form an eye-catching shape to command attention. As readers turn the pages, the various sizes of type denote the relative importance of each story, while special type motifs help them to recognize regular features. Overall the balanced and repeated use of certain typefaces helps to give the page a visual character instantly recognizable by readers as being different from other newspaper.

The body of newspaper is as follows [49]. 


\section{1) Advertisements}

It is the element over which the editor normally has no control. At the start of each day (or weekly papers) a flat-plan of the paper is produced by the advertising department, containing the number of pages and showing which spaces on each page have been sold to advertisers.

The editorial layout has to accommodate these shapes. The type and content of an advertisement cannot be altered and only in the case of a serious clash with editorial content is an advertising position changed, or if an important story needs a special placing.

2) Headline

Newspaper pages have headlines of different sizes and widths, most of them in a matching type, but with the odd one or two in different type to give variety.

The biggest headline on a page is usually at the top of the page and mostly on the longest story. If it crosses the top of the page it is called a banner headline, or streamer, and its size and prominence indicate that this is the most important story. We call this the lead story. The streamer might have above it a smaller line of heading containing a separate statement. This is called a strap-line, a subsidiary or introductory headline which comes first and qualifies the main headline.

The second biggest, or second most prominent headline indicates the second most important story. That is called the half lead. The remaining stories with headlines at the top half of the page are called tops. These are usually single column, but can be double column or more depending on the shape of the page left available by the advertisements.

The lead story, the half lead and the various tops fill the main area of the page. There will still be left a few small places to fill, mostly in the bottom half. Here the stories of least importance are placed. They are usually called fillers and may consist of one, two or three paragraphs with the headline of may be one or two lines in small type.

The use of term "tops" dates back to the period when design was non-existent and all stories started at the top of the page, often with only a single column headline, and ran down on the fillers. The evolution from this "vertical layout" to "horizontal layout" marked the start of modern newspaper design in which stories with sizeable headlines were allowed to cross the page in several "legs", thus making "strength below the fold" possible.

\section{3) Text/Content}

It is the body matter or body setting of the various stories. It is usually set in a regular column-width, and in a standard size reading type which is increased in size only to give the first few paragraphs, or into intro, of a story prominence.

4) Pictures (Photo)

Pictures, the final ingredient in the page, are there, as was we have seen, not only to illustrate the stories, but also to help in the design by giving visual balance.

Pictures give a newspaper page much of its initial impact and help the page 
design. The news page can be passably well filled if its reporters follow a fairly set routine day by day; but photographers cannot take the same pictures day after day if it their pictures are to be more than wasted space.

A good news picture needs to grasp the essence of the news. It needs people in it, and the people, wherever possible, should be its major interest. Even if they are not, you still need people to give life and scale.

Newspaper pictures fall into two classes [50]:

1) Those which are interesting in their own right and which will attract the reader's attention regardless of what they are about.

2) Pictures that will illustrate a story and make it more vivid, sometimes regardless of the intrinsic merit of the photographs itself.

\subsection{Conflict as the Object of News}

The Existence of Israel-Palestine: History of Israel and Palestine Conflict. Israeli-Palestinian conflict is not a simple two-sided conflict, as if the whole nation of Israel (or even all those Jews of Israeli nationals) has a similar view, while the Palestinians have the opposite view. In both communities there are people and groups who advocate total territorial exclusion of other communities, some advocated a two-state solution, and some advocated a solution of two nations with a secular country which covers an area of contemporary Israel, the Gaza Strip, West Bank, and East Jerusalem.

1) End of the century-19-1920: Origin of conflict

a) 1897, the First Zionist Congress was held, and b) Balfour Declaration 1917. November 2, 1917, Balfour Declaration proclaimed British, who regarded the Jews and Arabs as a promise to establish a "homeland" for Jews in Palestine.

\section{2) 1920-1948: British Mandate of Palestine}

David Ben-Gurion proclaimed Israel's independence from Great Britain on May 14, 1948 under the portrait of Theodor Herzl.

a) Text 1922: Mandate of the League of Nations Palestine, b) British Mandate of Palestine, c) Arab Revolt 1936-1939.

Arab Revolt led by Amin al-Husseini. No fewer than 5000 Arabs were killed, largely by the British. Hundreds of Jews were also killed. Husseini flew to Iraq, then to the German, who was in the Nazi government.

a) Territory by the United Nations Partition Plan 1947, and b) Declaration of Establishment of the State of Israel, May 14, 1948.

Israel unilaterally declared itself as a Jewish state. British leave Palestine. Egypt, Syria, Iraq, Lebanon, Jordan, and Saudi Arabia are beating the drums of war against Israel.

3) $1948-1967$

a) Arab-Israeli War of 1948, b) 1949 Truce Agreement

April 3, 1949. Israel and the Arabs agreed to a ceasefire. Israel gets the excess region 50 percent more than was decided in the UN Partition Plan.

a) Palestinian Exodus. 
b) 1956 Suez War.

c) Palestine Liberation Organization (PLO) was officially established in May 1964.

d) 1967 Six Day War.

e) Khartoum Resolution.

f) The occupation of the Gaza Strip by Egypt.

g) Occupied West Bank and East Jerusalem by Jordan.

4) 1967-1993

a) Palestinian National Covenant was made in 1968, the Palestinians formally demanded Israel freeze.

b) 1970 War of attrition.

c) 1973 Yom Kippur War.

d) Egypt-Israel peace agreement at Camp David 1978.

e) Lebanon War 1982.

f) The first Intifada (1987-1991).

g) Gulf War 1990/1.

5) 1993-2000: Oslo Peace Process

a) Oslo Peace Accords between Palestinians and Israelis 1993

13 September 1993. Israel and the PLO agreed to mutually recognize the sovereignty of each. In August 1993, Arafat sat at a table with Israeli Prime Minister Yitzhak Rabin. The result was the Oslo Accords. Rabin was willing to withdraw its troops from the West Bank and Gaza Strip as well as give Arafat a chance to run a semiautonomous agency that can "govern" in the two regions. Arafat "recognizes the right of the State of Israel to exist securely and peacefully".

28 September 1995. Implementation of the Oslo Agreement. Palestinian Authority immediately stood up.

b) Al-Aqsa tunnel riots

September 1996. Al-Aqsa tunnel riots. Israel deliberately opened the tunnel to the Aqsa Mosque to lure the tourists, which is hazardous for the mosque's foundation. The battle lasted several days and casualties.

c) January 18, 1997 Israel willing to withdraw its troops from Hebron, the West Bank.

d) River Wye Agreement in October 1998 contains the Israeli withdrawal and the release of political prisoners and Palestinian willingness to implement the Oslo agreement items, including the matter of illegal arms sales.

e) May 19, 1999, Labor party leader Ehud Barak was elected prime minister. He promised to accelerate the peace process.

6) 2000-present: Al-Aqsa Intifada (The rise of al-Aqsa)

a) Al-Aqsa Intifada (2000-present).

March 2000, Israeli opposition leader visits Ariel Sharon to the Aqsa Mosque sparked riots. Aqsa Mosque is considered as one of the holiest places of Islam. The second wave of Intifada began.

b) Camp David 2000 Summit between Palestinians and Israel. 
c) March-April 2002 Israeli Defense to build the Wall in the West Bank and accompanied by a series of Palestinian suicide attacks.

d) July 2004 International Court of Justice set a limit defense construction violates international law and Israel would have knocked him out.

e) January 9, 2005 Mahmoud Abbas, of Fatah, was elected President of the Palestinian Authority. He replaces Yasser Arafat who died on 11 November 2004.

\subsection{Israel-Palestine Conflict as the Object of News}

\subsubsection{Conflict of Interest}

All journalists are liable to experience conflict of interest, even when the range activities outside their works are small. A simple desire not to do old friend harm can get in the way of a story. A conflict may arise when a frequent source expects, as a favor, a story to be overlooked or unnaturally pruned. Journalistic professionalism copes with these pressures a best it can [51].

British broadcasting faces more serious forms of conflict of interest. Personalities it has created, being commercially valuable as household names and, to a lesser extent, producers it has trained, are offered large sums of money by commercial interests while they are still in programmers. Most are careful not to compromise themselves, especially when they work for news and topical programmers where trust would be damaged by commercial connections. A few are not careful enough. The true extent of the problem is impossible to know because many of the activities that earn big money are not declared and are not publicly obvious.

Other forms of commitment by people in significant editorial roles have long and firmly been ruled out. These include working for a political party, campaigning for a controversial cause, and taking a stand on a disputed matter of public policy (other than a broadcasting issue). To take a stand-or to seem to take a stand-for a commercial interest is just as undesirable because it impinges on editorial detachment.

Programmed people have been known to take the view that quiet commitment, out of sight of the public, is acceptable, their argument being that what the public does not know about does not trouble it. Against this, viewers of a corporate video are television viewers as well and knowing that a presenter has taken their company shilling could stain their view of the presenter on the programmer. No secret is safe anyway. Popular newspaper, doing their jobs properly, can find out about them and if, in the questionable they would not be news either.

People determined to remain editorially clean follow the rule that if you would not want the public to know, do not do it-nor allow others to do it [52].

Although issues of Israel-Palestine conflict is interesting for every media, the way the media reports the issues would not be the same, even though the reports are very quite different. This happens due to a number of reasons such as the orientation of the media, standard of news objectivity, etc. 
News is written from a certain fact. Although in writing news a journalist has to put into account a number of principles such as honesty, justice, etc. He cannot be separated from some factors like government policy, ideology of the media, etc. This is the reason why reports on a certain fact made by media would sometimes or even very often be different from other media. According to [53] that impartiality is appreciated mainly because many events involve conflict and are open to alternative interpretations and evaluations. The standard of news objectivity has given rise to much discussion of journalistic media content, under various headings, especially in relation to some form of bias, different point of view, and also neutrality of presentation news which is the reverse of objectivity. Media refers to various means of communication. In another words, media is tools used to store and deliver information or data. For example, television, radio, and the newspaper are different types of media. Media could be classified into Printed media such as: 1) newspaper, magazine, tabloid, etc.; and 2) electronic media such as: radio, television, and internet. Internet divided into some types of feature in delivering information and news. They are online newspaper, online television, online shopping, online sport news, etc. This research will discuss about online newspaper, a researcher presents the two online media, https://www.republika.co.id/ and https://www.kompas.com/ in reporting conflict between Israel-Palestine. Based on such consideration it is quite important to understand how https://www.republika.co.id/ and https://www.kompas.com/ report the conflict between Palestine and Israel, and why the reports made by both online media often different from one to another.

\subsubsection{A Frame Perspective to Coverage of War}

[54] aims that the "default mode of operation for the press is to cover tension, conflict, and violence" [55]. Demonstrates in a comparative study that the media prefer to use war frames even while covering peace negotiations shows that the Irish media find conflict frames more attractive than conciliation frames reach this conclusion: "Clearly, the coverage of the four Asian conflicts is dominated by war journalism" [54]. "War journalism" is a mode of reporting which contains a hidden bias in favour of violence. It renders conflict opaque, obscuring the structural factors driving the cycle of violence and occluding the political steps necessary to interrupt and divert it.

Peace journalism, according to Galtung, is to make "audible and visible" the subjugated aspects of reality. [56] noted that peace journalism has been criticized as "agenda journalism" or an attempt to "get involved" in our stories. They argue that the journalist's gatekeeper role means any report has an agenda [57]. The non-objective, self-conscious journalistic intervention is premised in the ideas of public journalism, development journalism and peace journalism. The indicators of war-patriotism, national interest, anger, censorship and propaganda-often conspire to prevent objective reporting. [58] argues that war journalism covers several parties in the conflict arena, causes of the conflict and solutions are sought on the battleground, it is zero-sum-oriented-one side wins 
and the other side loses and news coverage only begins with the visible violence and visible consequences, such as the dead, casualties and material damage [59]. On the contrary, says that "Peace or Conflict Journalism explores the background of a conflict formation in order to make conflicts appear transparent to the audience". [60] argues that peace journalism seeks causes and way out to the conflicts on all sides and gives voice to the views of all adversaries [61]. "Peace or Conflict Journalism exposes lies, cover-up attempts and culprits on all sides; it reveals the suffering of all conflict parties. Due to its orientation towards solutions, this mode of crisis journalism dedicates particular attention to peace initiatives and reports on post-war developments".

Peace journalism and Development Journalism share similar characteristics-one saves society from devastations, the other saves it from miseries of poverty. Development journalism encourages Journalists to travel to remote areas, interact with the people, and report back. This type of journalism also looks at proposed government projects to improve conditions in the country, and analyzes whether or not they will be effective. Ultimately, the journalist may come up with proposed solutions and actions in the piece, suggesting ways in which they might be implemented. Often, this type of development journalism encourages a cooperative effort between citizens of the nation and the outside world. Development journalism is also used in a manner similar to that of investigative reporting. Viewed in this manner, the role of a development journalist is to examine critically the existing development programs and projects of government, compare the planned project with its actual implementation, and report any observed shortcomings [62].

Researchers found that development journalism could hardly gain a foothold among journalists in developing countries. Thus it is, perhaps, more likely that the concept of peace journalism will experience the same fate as Development Journalism [63].

This study is supported by framing theory-specifically, peace journalism frame and war journalism frame. [64] employed the term "peace journalism" since the 1970s, developed two opposing modes of reporting wars, namely "peace or conflict journalism" and "war or violence journalism". His classification of war journalism and peace journalism is based on four broad practice and linguistic orientations: peace/conflict, truth/propaganda, people/elites and solutions/differences. In contrast, war journalism is oriented in war/violence, propaganda, elites and victory. Peace journalism tries to condemn the conflict by showing the black and white of all sides, and to de-escalate by highlighting peace and conflict resolution as much as violence. Peace journalism seeks to minimize the rift between opposing parties by not repeating facts that demonize one side and set the stage for conflict. War or Violence Journalism reports on the conflict arena, focuses on who gets the upper hand in the war. It has a zero-sum-oriented coverage; is mostly based on the visible violence and visible consequences [65].

Frames are mental structures that help people understand reality as they 
perceive it. Defines "framing" as "the principles of organization, which govern social events". According to [66], framing is something of subjective involvement in an event. Describes news frames as cognitive schemata, and journalists commonly work with news frames to simplify, prioritize and structure the narrative flow of events. Framing is unavoidable in the course of news construction. It is the stage at which journalists identify problems, analyze reasons and make moral judgments. It says, "News frames are embodied in key words, metaphors, concepts, symbols and visual images emphasized in a news narrative" [67].

Although there exists an excellent body of literature and research on war journalism, most of the work on peace journalism is normative or prescriptive, outlining its benefits and detailing how it can be implemented.

Theoretically, peace journalism is supported by framing theory. There is no one standard definition of framing [68], but broadly, news framing refers to the process of organizing a news story, thematically, stylistically, and factually, to convey a specific story line. According to "to frame is to select some aspects of a perceived reality and make them more salient in a communicating text, in such a way as to promote a particular problem definition, causal interpretation, moral evaluation, and/or treatment recommendation for the item described" described a media frame as "the central organizing idea for news content that supplies a context and suggests what the issue is through the use of selection, emphasis, exclusion and elaboration". Frames package key ideas, stock phrases, and stereotypical images to bolster a particular interpretation [69].

Through repetition, placement, and reinforcement, the texts and images provide a dominant interpretation more readily perceivable, acceptable, and memorable than other interpretations argued that the concepts of agenda setting and framing represent a convergence, in that framing is an extension of agenda setting. In fact, the concept of framing has been explicated as second-level agenda setting (Jasperson et al., 1998; McCombs, 1994; McCombs \& Bell, 1996; McCombs \& Evatt, 1995; McCombs, Shaw, \& Weaver, 1997). Object salience is transmitted in the first level of the agenda-setting process. In the second level, framing, or indicator salience, illustrates how the media tell us how to think about something - a reprisal of Bernard Cohen's famous statement that the media tell us what to think about. Framing is found to activate specific thoughts and ideas for news audiences, as seen in the vast body of framing effects research (e.g., Iyengar, 1991; McLeod \& Detenber, 1999; Price, Tewksbury, \& Powers, 1997; Sotirovic, 2000).

Several studies have focused on the framing of war reporting. identified four frames used in the framing of the Arab-Israeli conflict: strategic interests, feuding neighbors, Arab intransigence, and Israeli expansionism found that the media's pursuit of "drama" frames in the Middle East conflict accorded the extremists from both sides more than their due share of air time, while drowning voices calling for peace suggested that the media, subjected to state and military censorship, employed the same values and priorities in reporting conflict as in cov- 
ering other events. As a result, mass media become willing accomplices in wartime propaganda and may even play a role in instigating conflict found that the embedded journalist coverage of the 2003 war on Iraq was framed more favorably than non embedded reporting toward the US military.

\subsubsection{War and Peace: Two Competing Frames}

The author viewed peace journalism and war journalism as two competing frames in the coverage of a conflict. His classification of war journalism and peace journalism is based on four broad practice and linguistic orientations: peace/conflict, truth, people, and solutions. In contrast, war journalism is oriented in war/violence, propaganda, elites, and victory. Galtung's labeling of peace journalism as both peace- and conflict-oriented may appear paradoxical, but in reality, peace-oriented journalists must first accept that a conflict exists and explore conflict formations by identifying the parties, goals, and issues involved. The journalists understand the conflict's historical and cultural roots, and by giving voice to all parties (not only two opposing sides), create empathy and understanding [70].

Through careful, consistent, and conscientious application of peace journalism practices, the peace journalist hopes to create a setting in which the causes of and possible solutions to the conflict become transparent. Other peace journalism approaches include taking a preventive advocacy stance-for example, editorials and columns urging reconciliation and focusing on common ground rather than on vengeance, retaliation, and differences-and emphasizing the invisible effects of violence (e.g., emotional trauma and damage to social structure). In contrast, war journalism plays up conflict as an arena where participants are grouped starkly into two opposing sides ("them vs. us") in a zero-sum game and focuses on visible effects of war (casualties and damage to property).

Classification of war/peace journalism was expanded by into 17 good practices in covering war. Advice to journalists included focusing on solutions, reporting on long-term effects, orientating the news on ordinary people, reporting on all sides, and using precise language offered a peace journalism manual based on the Mindanao conflict that clarifies differences between Muslims and Christians and, more importantly, their common grounds. Advice included avoiding mention of culturally offensive issues such as the pork eating of Christians and the polygamous practice of Muslims. Another important principle is linguistic accuracy. "Rebels" should be identified as dissidents of a particular political grouping and not simply "Muslim rebels".

The unit of analysis was the individual story, a definition that included "hard" news stories, feature stories, opinion pieces, and letters to the editor. The stories, content analyzed by six mass communication graduate students between March and May 2003, were harvested from issues published during a specific period of conflict: February 15-May 31, 2002 (Kashmir); February 10-17, 2003, and April 1-June 30, 2000 (Philippine Mindanao conflict); August 1, 2001-February 28, 
2002 (Sri Lankan Tamil Tigers); and January 19-April 18, 1999, October 1-December 31, 2001, and March 1-August 31, 2002 (Indonesia's Maluku and Aceh civil wars).

These periods represented the most recent peak periods of these conflicts (some of which date back at least 5 decades) at the time of the study. The February 15-May 31, 2002, period was a particularly tense episode between Pakistan and India following a December 13, 2001, terrorist attack on the Indian parliament that was blamed on Pakistan and an ensuing heated exchange of words that sent the two neighbors to the brink of nuclear war. From March to June 2000, former Philippine President Estrada declared an "all-out war policy" against the Mindanao groups, and February 10-17 saw one of the bloodiest skirmishes between Mindanao's Moro Islamic Liberation Front (MILF) 1 and the Philippine armed forces.

The coding categories for frames are based on classification, involved indicators of war journalism and indicators of peace journalism. These indicators, used to elicit from the body text of each story which frame-war or peace journalism-dominated the narrative, comprised two themes: approach and language. The approach-based criteria included: a) reactivity, b) visibility of effects of war, c) elite orientation, d) differences, e) focus on here and now, f) good and bad dichotomy, g) party involvement, h) partisanship, i) winning orientation, and $j$ ) continuity of reports. The language-based criteria focused on language that was a) demonizing, b) victimizing, and c) emotive. For example, a story was judged if it is reactive ("Does it wait for war to break out before reporting it?"); whether it reported mainly on the visible effects of war ("Does it focus on casualties, death toll, damage to property?"); and whether it was partisan ("Is it biased for one side in the conflict?"), and so on. In this way, indexes were produced to measure war journalism and peace journalism. Based on the scores, the coder classified the story as war journalism, peace journalism, or neutral.

Based on the literature of the 10 categories used in this study, approach-based criteria included: attack, negotiations, expansion, cease fire, and offensive, while on language-based criteria are: assistance, demonstrating, victim, and Cooperation agreement.

\subsubsection{Formulation of Hypotheses}

It argues that Media frame building occurs as journalists "select some aspects of a perceived reality and make them more salient in a communicating text in such a way as to promote a particular problem definition, causal interpretation, moral evaluation, and/or treatment recommendation for the item described". This can be achieved in the media by the "presence or absence of certain keywords, stock phrases, stereotyped images, sources of information, and sentences that provide thematically reinforcing clusters of facts or judgments" Following the above discussion, on balance, we propose:

"Have different two online media reports the conflict between Israel-Palestine 
perceived from the topics and the content".

\section{Methodology}

\subsection{The 10 Categories}

1) Attack is the start of something dangerous and damaging, often in relation to some type of chemical substance. An attack is when battery acid begins to corrode and destroy the battery itself. The attack also detects when a military unit building of the enemy, and she begins heavy fire and shelling.

2) Negotiation both of the above perspectives hinge on different assessments about the role of trust and political risk in bargaining relationships among combatants in civil conflict situations. Communication-based approaches argue that the foundations for trust and reciprocal bargaining can be laid through a sustained process of dialogue and communication, especially if there are forums for dialogue and negotiation that allow the parties to treat each other as individuals, break down stereotypes, and identify common interests and needs. Realists argue that the parties will not be interested in negotiations as long as they continue to believe that they can pursue their goals through violent means. And once they do sit down at the negotiating table, communication and dialogue, though viewed as desirable, are often not enough to overcome the high levels of mistrust that infect intercommunal relationships in war-torn settings.

Agreement: State of agreeing; harmony of opinion, statement, action, or character; concurrence; concord; conformity; as, a good agreement subsists among the members of the council Concord or correspondence of one word with another in gender, number, case, or person. A concurrence in an engagement that something shall be done or omitted; an exchange of promises; mutual understanding, arrangement, or stipulation; a contract. The language, oral or written, embodying reciprocal promises.

\subsection{Cease Fire}

A cease fire is when two opposing armies agree to stop fighting temporarily. This can be an agreement between 2 large armies or 2 small groups on the battlefield. The terms of the cease-fire has to be agreed to on the spot so this is a risky time as either side could accidently start fighting again This is not the same as a Truce. Sometimes a battle or a war wears down both sides and they call a cease-fire in order to discuss a truce or negotiate for a surrender. The most common application was a cease-fire to attend the wounded and remove the dead.

\subsection{Demonstration}

He act, process, or means of making evident or proving, an explanation by example, experiment, a practical showing of how something works or is used; specif., such a showing of a product in an effort to sell it a display or outward show: 
a demonstration of grief a public show of feeling or opinion, as by a mass meeting or parade a show of military force or preparedness a logical proof in which a certain conclusion is shown to follow from certain premises.

\subsection{Victim}

Definition of a Victim, The Department of Justice Canada defines a victim as “... any person who is harmed, killed, or suffering as a result of an accidental or intentional act or situation. The victim may experience suffering and loss, e.g. physical, psychological, emotional, financial, social, medical, and others". The important points of this definition include:

Any person-anyone can become a victim and there may be one victim or many victims from any situation. Harmed, killed or suffering-there can be primary, secondary or tertiary victims involved in any situation.

\subsection{Cooperation}

Voluntarily arrangement in which two or more entities engage in a mutually beneficial exchange instead of competing. Cooperation can happen where resources adequate for both parties exist or are created by their interaction. The act of cooperating, or of operating together to one end; joint operation; concurrent effort or labor. The association of a number of persons for their benefit. Cooperation describes people working together to achieve results or people helping each other out to achieve a common goal. An example of cooperation is when one person hands you a brick and you lay the brick.

Causing someone to feel resentful, upset, or annoyed: the allegations made are deeply offensive to us offensive language (of a sight or smell) disgusting; repulsive: an offensive odour [Attributive] actively aggressive; attacking: offensive operations against the insurgents (of a weapon) meant for use in attack: he is also accused of possessing an offensive weapon chiefly North American relating to the team in possession of the ball or puck in a game: Shell was an outstanding offensive tackle during his 15 years with the Raiders.

Type of the Study. The type of the research is quantitative research, categorizing textual units is considered the most elementary from of measurement. In brief, descriptive quantitative research is a research employing the method of collecting, describing, classifying and analyzing the data and then drawing conclusion. The data can be sentences, discourse, pictures diary and memorandum. By using the descriptive method, this research is aimed to describe how Indonesian online newspaper report conflict between Israel and Palestine based on content analysis approach.

Research Object. Objects examined in this study are searching about news conflict between Palestine and Israel in two online news media: Kompas.com, and Republika Online (republika.co.id). Two of the online news media, researcher took the news about Palestine and Israel conflict during 2 years of observation. Expected, the results of research to answer the problem statements in 
this research.

Expansion is the act of getting bigger or something added onto something else. The phase of the business cycle when the economy moves from a trough to a peak. It is a period when business activity surges and gross domestic product expands until it reaches a peak. An expansion is one of two basic business cycle phases. The other is contraction (Ambardi, Mapping Digital Media: Indonesia (A Report by The Open Society Foundations), 2014).

Type of the Study. The type of the research is quantitative research, categorizing textual units is considered the most elementary from of measurement. In brief, descriptive.

\subsection{Assistance}

Assistance is the act of helping or lending support. An example of assistance is when someone may walk a dog for someone who is ill and unable to do so. The action of helping someone by sharing work: the work was completed with the assistance of carpenters the provision of money, resources, or information to help someone: schemes offering financial assistance to employers she will be glad to give advice and assistance.

Quantitative research is a research employing the method of collecting, describing, classifying and analyzing the data and then drawing conclusion. The data can be sentences, discourse, pictures diary and memorandum. By using the descriptive method, this research is aimed to describe how Indonesian online newspaper report conflict between Israel and Palestine based on content analysis approach.

Research Object. Objects examined in this study are searching about news conflict between Palestine and Israel in two online news media: Kompas.com, and Republika Online (republika.co.id). Two of the online news media, researcher took the news about Palestine and Israel conflict during 2 years of observation. Expected, the results of research to answer the problem statements in this research.

Sample and Sampling Research. The sample, in this study were all news topic about Palestine-Israel from media online news Kompas (kompas.com), and Republika Online (republika.co.id), related to the in 2009-2010 observations. Sampling is a method of collecting information from a sample that is representative of entire population. There are both advantages and disadvantages of both the methods. Whereas data from census is reliable and accurate, there is a margin of error in data obtained from sampling.

At this method study using census method. A census is a study that obtains data from every member of a population. In most studies, a census is not practical, because of the cost and/or time required. A census involves the gathering of information from every person in a certain group. This may include information on age, sex and language among others. A sample survey on the other hand commonly involves gathering data from only a certain sec- 
tion of a particular group. Census refers to periodic collection of information about the populace from the entire population. Census refers to periodic collection of information about the populace from the entire population (Sutherland, 1998).

We using ten categories from lead news about conflict Israel and Palestine publish 2009-2010, from 1403 news (population) by republika.com and kompas.co.id.

\section{Findings and Analysis of Findings}

\subsection{Online Media News Topics}

A summary about Israel-Palestine conflict from 2009 to 2010 published on Kompas and Republika online newspapers is presented before data analysis. Below is the summary.

Table 1 describes that in 2009 Kompas tended to publish negotiation news. There were 106 negotiation news topics. Meanwhile in 2010 Kompas Published 47 negotiation news topics. It is a bit less than what Republika published.

In 2009 Republika focused on negotiation news. There were 61 negotiation news topics. However, in 2010 Republika focused more on victim news. There were 78 victim news topics.

\subsection{Comparison between News about Kompas and Republika in $2009 / 2010$}

Chi-Square analysis in this research is used to compare the different publication between both online media, Kompas and Republika in 2009 and 2010 based on

Table 1. Frequency of news.

\begin{tabular}{ccccccccc}
\hline \multirow{2}{*}{ Topics } & \multicolumn{3}{c}{ Kompas } & \multicolumn{5}{c}{ Republika } \\
\cline { 2 - 9 } & 2009 & $\%$ & 2010 & $\%$ & 2009 & $\%$ & 2010 & $\%$ \\
\hline Attack & 43 & 9.77 & 30 & 12.61 & 55 & 15.36 & 67 & 18.26 \\
Negotiation & 106 & 24.09 & 47 & 19.75 & 61 & 17.04 & 70 & 19.07 \\
Agreement & 37 & 8.41 & 12 & 5.04 & 21 & 5.87 & 14 & 3.81 \\
Cease fire & 41 & 9.32 & 43 & 18.07 & 64 & 17.88 & 55 & 14.99 \\
Demonstration & 23 & 5.23 & 3 & 1.26 & 9 & 2.51 & 12 & 3.27 \\
Victim & 68 & 15.45 & 35 & 14.71 & 45 & 12.57 & 78 & 21.25 \\
Cooperation & 29 & 6.59 & 22 & 9.24 & 38 & 10.61 & 17 & 4.63 \\
Expansion & 22 & 5.00 & 13 & 5.46 & 15 & 4.19 & 16 & 4.36 \\
Offensive & 31 & 7.05 & 14 & 5.88 & 25 & 6.98 & 9 & 2.45 \\
Assistance & 40 & 9.09 & 19 & 7.98 & 25 & 6.98 & 29 & 7.90 \\
Total & 440 & $100 \%$ & 238 & $100 \%$ & 358 & $100 \%$ & 367 & $100 \%$ \\
\hline
\end{tabular}


10 news topics. The chi-square formula is:

$$
\chi^{2}=\Sigma \frac{(O-E)^{2}}{E} \quad \text { (Weinberg and Schumaker, 1969:212) }
$$

where:

$\chi^{2}=$ Chi-Square.

$O=$ Actual frequency or number of observations in a cell.

$E=$ Expected frequency or number of observations in a cell in the theoretical distribution.

$\Sigma=$ Symbol for "summation" the differences are cumulative.

\subsection{Analysis of Findings}

Based on the chi-square test, the complete discussion is as follows.

Table 2 shows that in 2009 Kompas was more dominant in publishing news about conflict between Israel and Palestine, with average 44 news from 10 topics, while in 2010 Republika published more news about conflict between Israel and Palestine, with average 37 news from 10 topics.

The analysis shows that overall both media issue different topics and have different point of view to present news about Israel-Palestine conflict in 2009-2010.

The results show for the news category "attack" the online media republika and Kompas there is no significant difference during the year 2009-2010 $\left(\chi^{2}=\right.$ $3.49<3.84 ; \mathrm{p}>0.05)$. There is no significant difference between reporting on attack in 2009 with 2010 despite dominating the news as much as 122 republika news (see Table 2).

There are significant differences between the Kompas and online republika in reporting news of the negotiation topic category in which observations from 2009-2010, it can be seen in the $\chi^{2}=29.06>3.84$ with probability value $(\mathrm{p})<$ 0.05 . Kompas news reported as many as 153 news category negotiation or by $53.9 \%$, while republika news just reported as many as 131 or by $46.1 \%$ of the

Table 2. Complete analysis result.

\begin{tabular}{|c|c|c|c|c|c|}
\hline \multirow{2}{*}{ Topics } & \multicolumn{2}{|c|}{ Kompas } & \multicolumn{2}{|c|}{ Republika } & \multirow{2}{*}{$\chi^{2}$ value } \\
\hline & 2009 & 2010 & 2009 & 2010 & \\
\hline Attack & $9.77 \%$ & $12.61 \%$ & $15.36 \%$ & $18.26 \%$ & 3.49 \\
\hline Negotiation & $24.09 \%$ & $19.75 \%$ & $17.04 \%$ & $19.07 \%$ & $29.06^{*}$ \\
\hline Agreement & $8.41 \%$ & $5.04 \%$ & $5.87 \%$ & $3.81 \%$ & $24.85^{*}$ \\
\hline Cease fire & $9.32 \%$ & $18.07 \%$ & $17.88 \%$ & $14.99 \%$ & 0.99 \\
\hline Demonstration & $5.23 \%$ & $1.26 \%$ & $2.51 \%$ & $3.27 \%$ & $18.77^{*}$ \\
\hline Victim & $15.45 \%$ & $14.71 \%$ & $12.57 \%$ & $21.25 \%$ & $19.43^{*}$ \\
\hline Cooperation & $6.59 \%$ & $9.24 \%$ & $10.61 \%$ & $4.63 \%$ & $19.69^{*}$ \\
\hline Expansion & $5.00 \%$ & $5.46 \%$ & $4.19 \%$ & $4.36 \%$ & 3.08 \\
\hline Offensive & $7.05 \%$ & $5.88 \%$ & $6.98 \%$ & $2.45 \%$ & $33.19^{*}$ \\
\hline Assistance & $9.09 \%$ & $7.98 \%$ & $6.98 \%$ & $7.90 \%$ & $9.45^{*}$ \\
\hline
\end{tabular}

Note: ${ }^{*}$ level significance $5 \%(0.05)$. 
total 284 news during the year 2009-2010. There are significant differences between the Kompas and online republika in reporting news about the topic category agreement in the observations of 2009-2010, it can be seen in the value $\chi^{2}=$ $24.85>3.84$ with probability value $(\mathrm{p})<0.05$, can be seen in Table 6 that Kompas preach more about the agreement (49) or by $58.3 \%$, compared republika (35) or by $41.7 \%$. There is no significant difference between the amount of news from the online news media (Kompas and republika) in 2009 to 2010, it can be seen on the acquisition value of $\chi^{2}$ of $0.99<3.84$ with probability value $>0.05$. In Table 8 republika more preaching about the cease fire (119 news or by $58.6 \%$ ) than the Kompas ( 84 news, or by 41.4\%) between 2009 and 2010. There are significant differences between the two media news online (Kompas and republika) in 2009 to 2010, it can be seen on the acquisition value of $\chi^{2}=18.77>3.84$ with probability value $<0.05$. During the years $2009-2010$ online news media dominated the news of the demonstration Kompas as many as 26 news (55.3\%), whereas only about 21 news republika (44.7\%). There are significant differences in reporting on victim in 2009 to 2010 of the online news media (Kompas and republika), it can be seen in the $\chi^{2}=19.43>3.84$ or the probability value $<0.05$. Total news about the victim, the news media to dominate online republika (a lot) that is equal to 123 (54.4\%), while the Kompas as many as 103 (45.6\%).

The preaching of the cooperation of both the online news media differed significantly between 2009 to 2010 , it can be seen in the $19.69>3.84$ or acquisition probability value $<0.05$. Republika preach about cooperation as much as 55 news (51.9\%) during 2009-2010, while the kompas is only 51 news (48.1\%). The average news about Israel expansion against Palestine did not differ significantly between the years 2009 to 2010 of both the online news media are examined, it can be seen on the acquisition value of $\chi^{2}=3.08<3.84$ or the acquisition value of probability $>0.05$. Table 15 can be seen that during the years 2009-2010 compass preach more about the expansion of Israel to Palestine (35 news, or by 53.0\%) while republika news just reported by 31 (47.0\%). News about offensive category there are significant differences between the years 2009 to 2010 in both the online news media are examined, it can be seen in the $\chi^{2}=33.19>3.84(\mathrm{p}<0.05)$. On Table 18 can be seen during the years 2009-2010 Kompas so much more to discuss news about offensive category ( 45 news or by $47.0 \%$ ), whereas only about 34 Republika news (43.0\%).

Categorized news content assistance between 2009 to 2010 of the online news media differ significantly, it can be seen on the acquisition value of $\chi^{2}=9.45>$ 3.84 with the probability $<0.05$. Online news media reported the Kompas far more assistance category (59\% or $52.2 \%$ ) compared to only 54 Republika news (47.8\%) during 2009-2010.

Research findings indicate that hypothesis is proven (hypothesis research are supported), it can be seen on the test results of 10 categories, 7 category showed a significant difference $\left(\chi^{2}>3.84\right)$ between the two online news media (republika and kompas) to provide news about the conflict between Israel and Palestinian, while only three news category that does not have significant differences are: at- 
tack, cease fire, and expansion $\left(\chi^{2}<3.84\right)$.

\section{Conclusions and Implication}

\subsection{Conclusions}

Based on the results of data analysis and discussion in the previous chapter, the conclusions obtained are as follows:

1) News categories: attack, cease fire, and expansion are significantly not different between the years 2009 and 2010 of the online news media studied (kompas and republika), it can be seen on the acquisition value of $\chi^{2}<3.84\left(\chi_{\text {table }}^{2}\right)$ or has a probability value $>0.05$. The seven categories of news, namely: negotiation, agreement, demonstration, victim, cooperation, offensive, and assistance have value $\chi^{2}>3.84\left(\chi_{\text {table }}^{2}\right)$ or have a probability value $<0.05$, which means that the category of news between 2009 and 2010 has a different number of news media coverage of both online media (kompas and republika).

2) Both Republika and Kompas the online media that have characterized kompasin conveying news about the conflict between Israel and the Palestinians. Both the online media have presented the news about Israel and the Palestinian conflict with a good, impartial one of the country experiencing conflicts. So everything is presented in a balanced and candid way. The majority of Indonesia people do not like the aggression committed by Israel against the Palestinians. These results can be seen from the comments/responses given on the news-reporting, either by kompas.com or by republika.co.id.

3) Although daily news reporting on the Israeli-Palestinian conflict can be preached more than once, the news content is not the same. There must be some distinction between news with each other. It can be seen on the classification in the appendix that it reporting about the same thing that Israel Conflict-Palestine preaching but the content is different. This is according to the author as clever journalists to compete and use them in conveying the character of the preaching of a message. The same news is not necessary for the content of the news presented in the same form, but the content is varied and written in a standard means that the online media journalists use language that can be understood by various circles anywhere, so read the online media users can instantly understand the contents of the good news. Word-a foreign word elusive will we rarely meet. But according to news content authors will be strongly influenced by who the readers. If readers have qualified human resources so the news is filtered and then received and understood the logic is not accompanied by emotion. But when news of the Israeli-Palestinian conflict and cause emotions to read and not understood the logic of the news is presented can affect the reader emotionally. So according to the authors the role of journalists are required to present the news, especially regarding the Israeli-Palestinian conflict with an impartial news content of one of the countries experiencing conflict and present it without adding or reducing the available facts. News that presents the contents 
of the news accurately and reliably will direct readers to see news that is international incident.

Kompass and republika media online tend not to take sides and judge the conflict between Israel and the Palestinians in neutral, to convey what happened in accordance with the existing circumstances.

4) Internet presence is very supportive of Internet users to find out what's happening in the world quickly. In every hour of many world events that can be preached. Kompas and Republika are the two biggest online media that have weight-quality coverage than the media-other online media. During the years 2009-2010 Republika reported more conflicts as many as 725 news tends to preach to the direction of freedom of the Palestinian people. Unlike the Kompas that tends to look at the social-political conflict between Israel and the Palestinians in terms of human rights and humanitarian rights with news from the years 2009-2010 the number of 678 news.

\subsection{Implication}

Theoretical Implications: Content analysis in theory help the reader to understand the contents of a text in depth, does not stop at a given word but rather the meaning and results of communication that occurs. With content analysis one would better understand a passage for receiving a message not only limited to the language used but also the interpretation of a person reading the news will affect a person in the receiving and capturing a message.

In this study, content analysis is used in analyzing the news Conflict Israel-Palestine is the right step for a news content such as text and contains a wide coverage and is of a medium mass media, the news of a general nature or the public, so that the content analysis is valuable for many downloader's news via the internet to digest the news.

Practical Implications: Reuters and the Reuters online media have become mass media in Indonesia is robust and reliable compared with other online media. Both the mass media is quite accessible many people in the State of Indonesia. Besides, the two mediums are the daily also because the media is first established as a leading print media and quality.

As users write messages and information media, especially in contemporary times has been a lot of online media (electronic media) that appears, then the content analysis needs to be done to filter the news through content or content that belongs in the news. In this study of course content at language is Conflict Israel-Palestine then the contents are very influential in the downloader's to interpret the information. Israeli-Palestinian conflict over the issue of racial intolerance, if readers cannot review the content analysis of news in the emotionally can have a negative influence when the downloader's actually presented the information to be found solving, thinking, and positive responses from news downloader's.

Table 3 attack news showed in this study compared two Indonesian online 
Table 3. Attack news.

\begin{tabular}{|c|c|c|c|c|}
\hline \multicolumn{5}{|c|}{ Attack } \\
\hline & Media & Kompas & Republika & Total \\
\hline \multirow{2}{*}{ YEARS } & 2009 & 43 & 55 & 98 \\
\hline & 2010 & 30 & 67 & 97 \\
\hline \multicolumn{2}{|c|}{ Total } & 73 & 122 & 195 \\
\hline
\end{tabular}

newspapers (the Kompas.com and the Republika.co.id) in the coverage of the conflict between Palestine and Israel, regarding attack news topic in 2009 and 2010 which was dominated by Republika.

Table 4 in Chi-square test result for attack news between Kompas and Republika in 2009 and 2010 shows the value of $\chi^{2}$ is 3.49 less than $3.84\left(\chi_{\text {table }}^{2}\right)$, where level significance is $5 \%$ with $\mathrm{df}$ equals 1 , meaning that there is no a significant difference between those two online media.

Table 5 negotiation news in The study compared two Indonesian online newspapers (the Kompas.com and the Republika.co.id) in the coverage of the conflict between Palestine and Israel in 2009 and 2010 about negotiation news which was dominated by Kompas in 2009 (106 news), while in 2010 Republika dominated with 70 news.

Table 6 in Chi-square test result for negotiation news between Kompas and Republika in 2009 and 2010 shows the value of $\chi^{2}$ is 29.06, more than 3.84 $\left(\chi_{\text {table }}^{2}\right)$, where level significance is $5 \%$ with df equals 1 , meaning that there is a significant difference on negotiation news between those two online media.

The difference that it can be seen Table 4 negotiation news in 2009 kompas publication with 106 news from the total 167 news but Republika publication less than Kompas with 61 news from the total 167, in 2010 kompas publication with 47 news from the total 117 news but Republika publication more than Kompas with 70 news from the total 117 news.

Table 7 showed In 2009 Kompas dominated publication about Israel-Palestine conflict on agreement news with 37 news, while in 2010 Republika dominated with 14 news.

Table 8 in Chi-square test result for negotiation news between Kompas and Republika in 2009 and 2010 shows the value of $\chi^{2}$ is 24.85 more than 3.84 $\left(\chi_{\text {table }}^{2}\right)$, where level significance is $5 \%$ with df equals 1 , meaning that there is a significant difference on agreement news between those two online media.

The difference between the two online media on agreement news that can be seen Table 6 in 2009 Kompas publication about Israel-Palestine conflict on agreement news with 37 news from the total 58 but Republika publication less than kompas with news 21 from the total 58, in 2010 kompas publication with 12 news while Republika publication more than kompas with 14 news from the total 14.

In Table 9 for cease fire news, online media Republika dominated both in 2009 with 64 news and in 2010 with 55 news. 
Table 4. Chi-square test result for attack news.

\begin{tabular}{ccccccc}
\hline fo & fe & $($ fo $-\mathrm{fe})$ & $(\mathrm{fo}-\mathrm{fe})^{2}$ & $(\mathrm{fo}-\mathrm{fe})^{2} / \mathrm{fe}$ & $\chi^{2}$ table & Decision \\
\hline 43 & 36.69 & 6.31 & 39.85 & 1.09 & & \\
30 & 36.69 & -6.69 & 44.72 & 1.22 & & \\
55 & 60.69 & -5.69 & 32.34 & 0.53 & 3.84 & Ho Accepted \\
67 & 60.69 & 6.31 & 39.85 & 0.66 & & \\
& \multicolumn{2}{c}{$\chi^{2}=(\mathrm{fo}-\mathrm{fe})^{2} / \mathrm{fe}$} & & 3.49 & & \\
\hline
\end{tabular}

Table 5. Negotiation news.

\begin{tabular}{|c|c|c|c|c|}
\hline \multicolumn{5}{|c|}{ Negotiation } \\
\hline & Media & Kompas & Republika & Total \\
\hline \multirow{2}{*}{ YEARS } & 2009 & 106 & 61 & 167 \\
\hline & 2010 & 47 & 70 & 117 \\
\hline \multicolumn{2}{|c|}{ Total } & 153 & 131 & 284 \\
\hline
\end{tabular}

Source: Primary data.

Table 6. Chi-square test result for negotiation news.

\begin{tabular}{ccccccc}
\hline fo & fe & $(\mathrm{fo}-\mathrm{fe})$ & $(\mathrm{fo}-\mathrm{fe})^{2}$ & $(\mathrm{fo}-\mathrm{fe})^{2} / \mathrm{fe}$ & $\chi^{2}$ table & Decision \\
\hline 106 & 89.97 & 16.03 & 257.02 & 2.86 & & \\
47 & 89.97 & -42.97 & 1846.28 & 20.52 & & \\
61 & 53.97 & 7.03 & 49.44 & 0.92 & 3.84 & Ho Rejected \\
70 & 53.97 & 16.03 & 257.02 & 4.76 & & \\
& \multicolumn{2}{c}{$\chi^{2}=(\mathrm{fo}-\mathrm{fe})^{2} / \mathrm{fe}$} & & 29.06 & & \\
\end{tabular}

Table 7. Agreement news.

\begin{tabular}{|c|c|c|c|c|}
\hline \multicolumn{5}{|c|}{ Agreement } \\
\hline & Media & Kompas & Republika & Total \\
\hline \multirow{2}{*}{ YEARS } & 2009 & 37 & 21 & 58 \\
\hline & 2010 & 12 & 14 & 26 \\
\hline \multicolumn{2}{|c|}{ Total } & 49 & 35 & 84 \\
\hline
\end{tabular}

Table 8. Chi-square test result for agreement news.

\begin{tabular}{ccccccc}
\hline fo & $\mathrm{fe}$ & $(\mathrm{fo}-\mathrm{fe})$ & $(\mathrm{fo}-\mathrm{fe})^{2}$ & $(\mathrm{fo}-\mathrm{fe})^{2} / \mathrm{fe}$ & $\chi^{2}$ table & Decision \\
\hline 37 & 33.83 & 3.17 & 10.03 & 0.30 & & \\
12 & 33.83 & -21.83 & 476.69 & 14.09 & & \\
21 & 10.83 & 10.17 & 103.36 & 9.54 & 3.84 & Ho Rejected \\
14 & 10.83 & 3.17 & 10.03 & 0.93 & & \\
& $\chi^{2}=(\mathrm{fo}-\mathrm{fe})^{2} / \mathrm{fe}$ & & 24.85 & & \\
\hline
\end{tabular}

In Table 10 Chi-square test result for cease fire news between Kompas and Republika in 2009 and 2010 shows the value of $\chi^{2}$ is 0.99 less than $3.84\left(\chi_{\text {table }}^{2}\right)$, 
Table 9. Cease fire news.

\begin{tabular}{|c|c|c|c|c|}
\hline \multicolumn{5}{|c|}{ Cease fire } \\
\hline & Media & Kompas & Republika & Total \\
\hline \multirow{2}{*}{ YEARS } & 2009 & 41 & 64 & 105 \\
\hline & 2010 & 43 & 55 & 98 \\
\hline \multicolumn{2}{|c|}{ Total } & 84 & 119 & 203 \\
\hline
\end{tabular}

Source: Primary data.

Table 10. Chi-square test result for cease fire news.

\begin{tabular}{ccccccc}
\hline fo & fe & $($ fo $-\mathrm{fe})$ & $(\mathrm{fo}-\mathrm{fe})^{2}$ & $(\mathrm{fo}-\mathrm{fe})^{2} / \mathrm{fe}$ & $\chi^{2}$ table & Decision \\
\hline 41 & 43.45 & -2.45 & 5.99 & 0.14 & & \\
43 & 43.45 & -0.45 & 0.20 & 0.00 & & \\
64 & 57.45 & 6.55 & 42.93 & 0.75 & 3.84 & Ho Accepted \\
55 & 57.45 & -2.45 & 5.99 & 0.10 & & \\
& $\chi^{2}=(\mathrm{fo}-\mathrm{fe})^{2} / \mathrm{fe}$ & & 0.99 & & \\
\end{tabular}

where level significance is $5 \%$ with df equals 1 , meaning that there is not a significant difference on cease fire news between those two online media.

Table 11 In 2009 Kompas dominated demonstration news publication with 23 news, while Republika dominated in 2010 with 12 news.

Table 12 in Chi-square test result for Demonstration news show that there is a significant difference between Kompas and Republika when publishing demonstration news. It can be seen from the value of $\chi^{2}$ is 18.77 more than 3.84 $\left(\chi_{\text {table }}^{2}\right)$, where level significance is $5 \%$ with df equals 1 . The difference between kompas and republika when publishing demonstration news can be seen in from Table 10, in 2009 Kompas publication demonstration news with 23 but republika with 9 news from the total 32 while in 2010 kompas publication with 3 news and republika more than kompas with 12 news from the total 15 .

Table 13 shows that from the total 113 victim news in 2009, Kompas dominated victim news publication with 68 news, while from the total 113 news Republika dominated in 2010 with 78 news.

There is a significant difference between Kompas and Republika when publishing victim news. It can be seen from the value of $\chi^{2}$ is 19.43 more than 3.84 $\left(\chi_{\text {table }}^{2}\right)$, where level significance is $5 \%$ with df equals 1 . The difference it can be seen Table 13 Victim news in 2009 Kompas publication with 68 news from the total 113 but Republika publication less than Kompas with 45 news from the total 113 while in 2010 Kompas publication with 35 news from the total 113 but Republika publication more than Kompas with 78 news from the total 113.

Table 14 shows in 2009 Republika dominated cooperation news publication with 38 news from the total 67 news, while Kompas dominated in 2010 with 22 news from the total 39 news.

Table 15 showed there is a significant difference between Kompas and Republika when publishing cooperation news. It can be seen from the value of $\chi^{2}$ is 
Table 11. Demonstration news.

\begin{tabular}{|c|c|c|c|c|}
\hline \multicolumn{5}{|c|}{ Demonstration } \\
\hline & Media & Kompas & Republika & Total \\
\hline \multirow{2}{*}{ YEARS } & 2009 & 23 & 9 & 32 \\
\hline & 2010 & 3 & 12 & 15 \\
\hline \multicolumn{2}{|c|}{ Total } & 26 & 21 & 47 \\
\hline
\end{tabular}

Source: Primary data.

Table 12. Chi-square test result for demonstration news.

\begin{tabular}{ccccccc}
\hline fo & fe & $($ fo $-\mathrm{fe})$ & $(\mathrm{fo}-\mathrm{fe})^{2}$ & $(\mathrm{fo}-\mathrm{fe})^{2} / \mathrm{fe}$ & $\chi^{2}$ table & Decision \\
\hline 23 & 17.70 & 5.30 & 28.07 & 1.59 & & \\
3 & 17.70 & -14.70 & 216.15 & 12.21 & & \\
9 & 6.70 & 2.30 & 5.28 & 0.79 & 3.84 & Ho Rejected \\
12 & 6.70 & 5.30 & 28.07 & 4.19 & & \\
& $\chi^{2}=(\mathrm{fo}-\mathrm{fe})^{2} / \mathrm{fe}$ & & 18.77 & & \\
\end{tabular}

Table 13. Victim news.

\begin{tabular}{cccccc}
\hline \multirow{4}{*}{ YEARS } & \multicolumn{5}{c}{ Victim } \\
\hline \multirow{6}{*}{} & Media & Kompas & Republika & Total \\
& 2009 & 68 & 45 & 113 \\
& 2010 & 35 & 78 & 113 \\
& Total & & 103 & 123 & 226 \\
\hline
\end{tabular}

Source: Primary data.

Table 14. Cooperation news.

\begin{tabular}{|c|c|c|c|c|}
\hline \multicolumn{5}{|c|}{ Cooperation } \\
\hline & Media & Kompas & Republika & Total \\
\hline \multirow{2}{*}{ YEARS } & 2009 & 29 & 38 & 67 \\
\hline & 2010 & 22 & 17 & 39 \\
\hline \multicolumn{2}{|c|}{ Total } & 51 & 55 & 106 \\
\hline
\end{tabular}

Table 15. Chi-square test result for cooperation news.

\begin{tabular}{ccccccc}
\hline fo & fe & (fo $-\mathrm{fe})$ & $(\mathrm{fo}-\mathrm{fe})^{2}$ & $(\mathrm{fo}-\mathrm{fe})^{2} / \mathrm{fe}$ & $\chi^{2}$ table & Decision \\
\hline 29 & 32.24 & -3.24 & 10.47 & 0.32 & & \\
22 & 32.24 & -10.24 & 104.77 & 3.25 & & \\
38 & 20.24 & 17.76 & 315.57 & 15.59 & 3.84 & Ho Rejected \\
17 & 20.24 & -3.24 & 10.47 & 0.52 & & \\
& $\chi^{2}=(\mathrm{fo}-\mathrm{fe})^{2} / \mathrm{fe}$ & & 19.69 & & \\
\hline
\end{tabular}

19.69 more than $3.84\left(\chi_{\text {table }}^{2}\right)$, where level significance is $5 \%$ with df equals 1 . The difference between two online media Kompas and Republika when publishing cooperation news it can be seen from Table 16 Cooperation news, in 2009 
Table 16. Chi-square test result for victim news.

\begin{tabular}{ccccccc}
\hline fo & fe & $($ fo $-\mathrm{fe})$ & $(\mathrm{fo}-\mathrm{fe})^{2}$ & $(\mathrm{fo}-\mathrm{fe})^{2} / \mathrm{fe}$ & $\chi^{2}$ table & Decision \\
\hline 68 & 51.50 & 16.50 & 272.25 & 5.29 & & \\
35 & 51.50 & -16.50 & 272.25 & 5.29 & & \\
45 & 61.50 & -16.50 & 272.25 & 4.43 & 3.84 & Ho Rejected \\
78 & 61.50 & 16.50 & 272.25 & 4.43 & & \\
& $\chi^{2}=(\mathrm{fo}-\mathrm{fe})^{2} / \mathrm{fe}$ & & 19.43 & & \\
\end{tabular}

Kompas publication cooperation news with 29 from the total 67 news but Republika publication more than Kompas with 38 news cooperation from the total 67 news while in 2010 Kompas publication with 22 news from the total 39 news but Republika less than Kompas publication with 17 news from the total 39 news.

Table 17 showed In 2009 Kompas dominated expansion news publication with 22 news from the total 37 news, while Republika dominated in 2010 with 16 news from the total 29 news.

There is not a significant difference between Kompas and Republika when publishing expansion news (as shown in Table 18). It can be seen from the value of $\chi^{2}$ is 3.08 less than 3.84 ( $\chi_{\text {table }}^{2}$ ), where level significance is 5\% with df equals 1 .

Table 19 showed In 2009 Kompas dominated offensive news publication with 31 news from the total 56 news, and Kompas dominated again in 2010 with 14 news from the total 23 news.

Table 20 showed there is a significant difference between Kompas and Republika when publishing offensive news. Kompas dominated in 2009 and 2010. It can be seen from the value of $\chi^{2}$ is 33.19 more than $3.84\left(\chi_{\text {table }}^{2}\right)$, where level significance is $5 \%$ with df equals 1 . The difference between the both online media it can be seen Table 18 offensive news, in 2009 and 2010 Kompas publication more than Republika with 31 offensive news in 2009 from the total 56 and in 2010 with 14 news from the total 23 but Republika less than Kompas in 2009 and 2010 publication with 25 news in 2009 from the total 56 and in 2010 with 9 news from the total 23 news.

Table 21 showed In 2009 Kompas dominated assistance news publication with 40 news from the total 65 news, while Republika dominated in 2010 with 29 news from the total 48 news.

Table 22 showed there is an average difference from the total number of assistance news between Kompas and Republika in 20009-2010. It can be seen from the value of $\chi^{2}$ is 9.45 more than 3.84 ( $\chi_{\text {table }}^{2}$ ), where level significance is $5 \%$ with $\mathrm{df}$ equals 1 , meaning that there is a significant difference in the number of assistance news between Kompas and Republika. Kompas publishes more news on assistance topic. The difference between Kompas and Republika when publishing assistance News it can be seen from Table 21 assistance news in 2009 kompas publication with 40 news assistance from the total 65 news but in 2009 republika less than Kompas publication 25 news from the total 65 news while in 
Table 17. Expansion news.

\begin{tabular}{ccccc}
\hline \multicolumn{5}{c}{ Expansion } \\
\hline \multirow{3}{*}{ YEARS } & Media & Kompas & Republika & Total \\
\hline \multirow{6}{*}{ Total } & 2009 & 22 & 15 & 37 \\
& 2010 & 13 & 16 & 29 \\
& & 35 & 31 & 66 \\
\hline
\end{tabular}

Table 18. Chi-square test result for expansion news.

\begin{tabular}{ccccccc}
\hline fo & fe & $($ fo $-\mathrm{fe})$ & $(\mathrm{fo}-\mathrm{fe})^{2}$ & $(\mathrm{fo}-\mathrm{fe})^{2} / \mathrm{fe}$ & $\chi^{2}$ table & Decision \\
\hline 22 & 19.62 & 2.38 & 5.66 & 0.29 & & \\
13 & 19.62 & -6.62 & 43.84 & 2.23 & & \\
15 & 13.62 & 1.38 & 1.90 & 0.14 & 3.84 & Ho Rejected \\
16 & 13.62 & 2.38 & 5.66 & 0.42 & & \\
& $\chi^{2}=(\mathrm{fo}-\mathrm{fe})^{2} / \mathrm{fe}$ & & 3.08 & & \\
\hline
\end{tabular}

Table 19. Offensive news.

\begin{tabular}{cccccc}
\hline \multirow{6}{*}{ YEARS } & Media & Kompas & Republika & Total \\
\hline \multirow{3}{*}{ YEA } & 2009 & 31 & 25 & 56 \\
& & 2010 & 14 & 9 & 23 \\
& Total & & 45 & 34 & 79 \\
\hline
\end{tabular}

Table 20. Chi-square test result for offensive news.

\begin{tabular}{ccccccc}
\hline fo & $\mathrm{fe}$ & $(\mathrm{fo}-\mathrm{fe})$ & $(\mathrm{fo}-\mathrm{fe})^{2}$ & $(\mathrm{fo}-\mathrm{fe})^{2} / \mathrm{fe}$ & $\chi^{2}$ table & Decision \\
\hline 31 & 31.90 & -0.90 & 0.81 & 0.03 & & \\
14 & 31.90 & -17.90 & 320.36 & 10.04 & & \\
25 & 9.90 & 15.10 & 228.05 & 23.04 & 3.84 & Ho Rejected \\
9 & 9.90 & -0.90 & 0.81 & 0.08 & & \\
& $\chi^{2}=(\mathrm{fo}-\mathrm{fe})^{2} / \mathrm{fe}$ & & 33.19 & & \\
\hline
\end{tabular}

Table 21. Assistance news.

\begin{tabular}{|c|c|c|c|c|}
\hline \multicolumn{5}{|c|}{ Assistance } \\
\hline & Media & Kompas & Republika & Total \\
\hline \multirow{2}{*}{ YEARS } & 2009 & 40 & 25 & 65 \\
\hline & 2010 & 19 & 29 & 48 \\
\hline \multicolumn{2}{|c|}{ Total } & 59 & 54 & 113 \\
\hline
\end{tabular}

Table 22. Chi-square test result for assistance news.

\begin{tabular}{ccccccc}
\hline fo & fe & $(\mathrm{fo}-\mathrm{fe})$ & $(\mathrm{fo}-\mathrm{fe})^{2}$ & $(\mathrm{fo}-\mathrm{fe})^{2} / \mathrm{fe}$ & $\chi^{2}$ table & Decision \\
\hline 40 & 33.94 & 6.06 & 36.75 & 1.08 & & \\
19 & 33.94 & -14.94 & 223.15 & 6.58 & & \\
25 & 22.94 & 2.06 & 4.25 & 0.19 & 3.84 & Ho Rejected \\
29 & 22.94 & 6.06 & 36.75 & 1.60 & & \\
& $\chi^{2}=(\mathrm{fo}-\mathrm{fe})^{2} / \mathrm{fe}$ & & 9.45 & & \\
\hline
\end{tabular}


2010 kompas publication with 19 from the total 48 news assistance but Republika publication more the Kompas with 29 news from the total 48 news.

\section{Conflicts of Interest}

The authors declare no conflicts of interest regarding the publication of this paper.

\section{References}

[1] Baran, S.J. and Davis, D.K. (2003) Mass Communication Theory: Foundation, Ferment, and Future. Thomson Learning Academic Resource Center, Canada.

[2] Barker, R.L. (1987) The Social Work Dictionary. NASW, Silver Spring, MD.

[3] Bell, P. and Reddy, P. (2004) Rural Areas and the Internet. Pew Internet \& American Life Project, Washington DC.

[4] Bittner, J.R. (1943) Mass Communication. Allyn and Bacon, Simon and Schuster Company.

[5] Boczkowski, P.J. (2004) Digitizing the News: Innovation in Online Newspapers. The MIT Press, Cambridge, MA. https://doi.org/10.7551/mitpress/2435.001.0001

[6] Bolter, J.D. and Grusin, R. (2000) Remediation: Understanding New Media. MIT Press, Cambridge, MA.

[7] Braman, S. and Roberts, S. (2003) Advantage ISP: Term of Service as Media Law. New Media and Society, 5, 422-448. https://doi.org/10.1177/14614448030053007

[8] Carey, J. (1989) Communication as Culture. Routledge, New York, London.

[9] Carruthers, S.L. (2000) The Media at War: Communication and Conflict in the Twentieth Century. St Martin's Press, New York.

[10] Castells, M. (2001) The Internet Galaxy. Reflections on the Internethe Internet Galaxy. Reflections on the Internet. Business and Society, Oxford University Press.

[11] Gringras, C. and Todd, E. (1997) Gringras on the Laws of the Internet. 3rd Edition, Butterworths, London and Charlottesville.

[12] Christians, C.G., Ferre, J. and Fackler, P. (1993) Good News. Oxford University Press, New York.

[13] DiMaggio, P. and Hargittai, E. (2002) From the 'Digital Divide' to 'Digital Inequality'. The Annual Meetings of the American Sociological Association in Chicago, Chicago, August 2001.

[14] Fawcett, L. (2002) Why Peace Journalism Isn't News. Journalism Studies, 3, 213-223. https://doi.org/10.1080/14616700220129982

[15] Flew, T. (2002) New Media an Introduction. Oxford University Press, New York.

[16] Galtung, J. (1986) On the Role of the Media in Worldwide Security and Peace. In: Varis, T., Ed., Peace and Communication, Universidad para La Paz, San Jose, Costa Rica, 249-266.

[17] Galtung, J. (1998) Peace Journalism: What, Why, Who, How, When, Where. Paper presented in the workshop, "What Are Journalists For?" TRANSCEND, Taplow Court, UK.

[18] Harris, G. and Spark, D. (2000) Practical Newspaper Reporting. Focal Press, Oxford.

[19] Gilder, G. (1994) Life after Television. W.W. Norton \& Co, New York. 
[20] Gunther, B. (2003) News and the Net. Lawrence Erlbaum Associates, Inc, Hillsdale, NJ.

[21] Hair, J.F., Black, W.C., Babin, B.J. and Anderson, R.E. (2010) Overview of Multivariate Methods., Pearson Prentice Hall, Upper Saddle River, NJ.

[22] Hanitzsch, T. (2004) Journalist as Peacekeeping Force? Peace Journalism and Mass Communication Theory. Journalism Studies, 5, 482-493. https://doi.org/10.1080/14616700412331296419

[23] Shaw, M. and Garlan, D. (1996) Software Architecture, vol. 101. Prentice Hall Englewood Cliffs.

[24] Hodgson, F. (1998) Modern Newspaper Practice: A Primer on the Press. Focal Press, Oxford.

[25] Iggers, J. (1998) Good News, Bad News: Journalism Ethics and the Public Interest. Westview, Boulder, CO.

[26] Carey, J.W. (1988) Communication as Culture: Essays on Media and Society.

[27] Keohane, R. (1984) After Hegemony: Cooperation and Discord in the World Political Economy. Princeton University Press, Princeton, NJ.

[28] Nye Jr., J.S. and Keohane, R.O. (2000) Power and Interdependence. 3rd Edition, Longman, New York.

[29] Knightley, P. (1975) The First Casualty. Harcourt Brace Jovanovitch, New York.

[30] Straubhaar, J. and LaRose, R. (2006) Communications Media in the Information Society. Wadsworth Publishing Company, Belmont, CA.

[31] Straubhaar, J.D. and LaRose, R. (2006) Media Now: Understanding Media, Culture, and Technology. Cengage Learning, Boston, MA.

[32] Lessig, L. (1999) Code and Other Laws of Cyberspace. Basic Books, Law Library, New York.

[33] Hass, R. (2009) Rejuvenation in Distinct Cell Populations-What Does It Mean? Experimental Gerontology, 44, 634-638.

[34] Lievrouw, L.A. and Livingstone, S. (2004) The Handbook of New Media. Sage, London, 136-151.

[35] Lichtenberg, J. (2000) Defense of Objectivity Revisited. In: Curran, J. and Gurevich, M., Eds., Mass Media and Society, 3rd Edition. Oxford University Press, London, 238-254.

[36] Heidelberg Institute on International Conflict Research (2005) Conflict Barometer 2005: Crises, Wars, Coups d'État, Negotiations, Mediations, Peace Settlements. 14th Annual Conflict Analysis. University of Heidelberg, Heidelberg.

[37] Lynch, J. (1998) Listening to the Outsiders. British Journalism Review, 9, 64-69. https://doi.org/10.1177/095647489800900310

[38] Trivundza, I.T. (2004) Orientalism as News: Pictorial Representations of the US Attack on Iraq in Delo. Journalism, 5, 480-499. https://doi.org/10.1177/1464884904044206

[39] Maslog, C.C. (1990) A Manual on Peace Reporting in Mindanao. Press Institute, Philippine.

[40] McCormack, M.H. (1997) On Negotiating. Newstar-Pr Media, Toronto.

[41] McQuail, D. (2000) Mass Communication Theory. Sage Publications, London.

[42] Mencher, M. (1999) Basic Media Writing. McGraw-Hill College, Boston, MA.

[43] Keith, M.C. (2000) The Radio Station. 5th Edition, Focal Press, Johannesburg, 
167-168.

[44] Moore, C. (1986) The Mediation Process: Practical Strategies for Resolving Conflict. Jossey-Bass, San Francisco, CA.

[45] Nierenberg, G.I. (1985) The Art of Negotiating. Dutton Adult, New York.

[46] Fiske, J., Hartley, J., Montgomery, M., O’Sullivan, T. and Saunders, D. (1994) Key Concepts in Communication and Cultural Studies. 2nd Edition, Routledge, London.

[47] Pedelty, M. (1995) War Stories: The Culture of Foreign Correspondents. Routledge, New York.

[48] Rogers, E.M. (1995) Diffusion of Innovations. 4th Edition, The Free Press, New York.

[49] Schramm, W. and Roberts, D.F. (1954) How Communication Works. In: The Process and Effects of Mass, University of Illinois Press, Champaign, IL.

[50] Baran, S.J. (2010) Introduction to Mass Communication Media Literacy and Culture. McGraw-Hill, New York.

[51] Stevens, S.S. (1946) On the Theory Scales of the Measurement. Science, 103, 677-680. https://doi.org/10.1126/science.103.2684.677

[52] Sutherland, W.J. (1998) Ecological Census Techniques: A Handbook. Cambridge University Press, Cambridge.

[53] Thussu, K.D. (2002) International Communication-Continuity and Change. Arnold, London.

[54] Van Ginneken, J. (1998) Understanding Global News: A Critical Introduction. Sage, Thousand Oaks, CA.

[55] Tuchman, G. (1978) Making News: A Study in the Construction of Reality. Sage, Beverly Hills, CA.

[56] Webel, C. and Galtung, J. (2007) Handbook of Peace and Conflict Studies. Routledge, London.

[57] LaRose and Straubhaar (2000) Communications Media in the Information Age. Wadsworth, a Division of Thomson Learning, United States of America.

[58] Weinberg, G.H. and Schumaker, J.A. (1969) Statistic: An Intuitive Approach. 3rd Edition, Brooks/Cole Pub. Co., 212.

[59] Wilmot, W.W. and Hocker, J.L. (1998) Interpersonal Conflict. 5th Edition, McGraw-Hill, New York.

[60] Wilson, J. (1996) Understanding Journalism. Routledge, London.

[61] Wolfsfeld, G. (1997) Promoting Peace through the News Media: Some Initial Lessons from the Peace Process. The International Journal of Press/ Politics, 2, 52-70. https://doi.org/10.1177/1081180X97002004005

[62] Gunther, A. (1988) Attitude Extremity and Trust in Media. Journalism \& Mass Communication Quarterly, 65, 279-287. https://doi.org/10.1177/107769908806500203

[63] Ambardi, K.K., Parahita, G., Lindawati, L., Sukarno, A. and Aprilia, N. (2014) Mapping Digital Media: Indonesia. Open Society Foundations, 1-92.

[64] Gilboa, E., Jumbert, M.G., Miklian, J. and Robinson, P. (2016) Moving Media and Conflict Studies beyond the CNN Effect. Review of International Studies, 44, 654-672. https://doi.org/10.1017/S026021051600005X

[65] Himelfarb, B.S. and Chabalowski, M. (2008) Media, Conflict Prevention and Peacebuilding. 1-5. 
[66] Piers, R. (1999) The CNN Effect: Can the News Media Drive Foreign Policy? Review of International Studies, 25, 301-309. https://doi.org/10.1017/S0260210599003010

[67] Gilboa, E. (2003) Media Coverage of International Negotiation: A Taxonomy of Levels and Effects. International Negotiation, 5, 543-568. https://doi.org/10.1163/15718060020848884

[68] Yiu, Y. and Saner, R. (2002) External Stakeholder Impacts on Third-Party Interventions in Resolving Malignant Conflicts: The Case of a Failed Third-Party Intervention in Cyprus. International Negotiation, 6, 387-416. https://doi.org/10.1163/15718060120849161

[69] Iyengar, S. and Hahn, K. (2009) Red Media, Blue Media: Evidence of Ideological selectivity in Media Use. Journal of Communication, 59, 19-39. https://doi.org/10.1111/j.1460-2466.2008.01402.x

[70] McGoldrick, A. (2000) Peace Journalism-An Introduction. In: Stiftung, F.E., Ed., Medien im Konflikt-Mittäter oder Mediatoren? The Media in Conflicts-Accomplices or Mediators? FES, Bonn, 19-24. 